\title{
RISK FACTORS FOR NONALCOHOLIC STEATOHEPATITIS IN CRYPTOGENIC CIRRHOSIS
}

\author{
Andrea Benevides LEITE ${ }^{1}$, Angelo Alves de MATTOS ${ }^{1,2}$, Angelo Zambam de MATTOS ${ }^{1,2}$, \\ Gabriela Perdomo CORAL ${ }^{1,2}$ and Sandro EVALDT ${ }^{3}$
}

\begin{abstract}
Context - In about 10\% of patients with chronic liver disease, it is not possible to identify an etiologic factor. These cases are called cryptogenic cirrhosis. Currently, nonalcoholic steatohepatitis (NASH) is being considered as a possible etiologic factor for a significant segment of patients that presents with cryptogenic cirrhosis. Objective - To estimate the prevalence of risk factors for NASH in patients with cryptogenic cirrhosis, in order to verify if there is a causal relationship between them. Method - Cross-sectional study, with evaluation of the demographic and laboratorial data of patients with cryptogenic cirrhosis. They were compared with data obtained from a group with NASH and a group with alcoholic and/or hepatitis C (HCV) cirrhosis. Results - Forty seven patients with cryptogenic cirrhosis were evaluated, 47 with NASH and 196 with HCV and/or alcoholic cirrhosis. The mean age of patients with cryptogenic cirrhosis was 52 years, while in those with NASH it was 46.4 years $(P=0,041)$. The group with cryptogenic cirrhosis had 23 female and 24 male patients. Of the patients who presented with NASH, $68.1 \%$ were female. Of the patients who presented with alcoholic/HCV cirrhosis, $64.8 \%$ were male. There were no statistically significant differences between the groups. In cryptogenic cirrhosis patients, the following prevalences could be observed: impaired fasting glycemia $-68.2 \%$; obesity $-27.5 \%$; total hypercholesterolemia - 27.9\%; low HDL levels - 58.1\% (women $-81 \%$; men - 36.4\%); hypertriglyceridemia - 16.3\%. The results seen in cryptogenic cirrhosis patients showed statistical similarity with the results of the NASH group regarding fasting glycemia (62.8\%) and male HDL levels (53.8\%). The comparison with the alcoholic/HCV cirrhosis group showed statistical differences regarding fasting glycemia (45.2\%), hypercholesterolemia (13.3\%) and female HDL levels (50.8\%). Conclusions - It is not possible to establish a causal relationship between cryptogenic cirrhosis and NASH. Only data related to fasting glycemia and HDL levels in male patients showed statistical similarities between both groups of patients.
\end{abstract}

HEADINGS - Liver cirrhosis. Fatty liver. Metabolic diseases.

\section{INTRODUCTION}

The prevalence of cryptogenic cirrhosis (CC) varies between $3-10 \%(6,7,18,23,26)$. A portion of these cases is attributed to non-alcoholic steatohepatitis (NASH), since, when cirrhosis is established, patients no longer present typical histological characteristics of $\mathrm{NASH}$, thus, preventing its clinical recognition ${ }^{(1,8,24)}$. A causal relationship between both entities could be suggested by the study of risk factors for NASH in patients with $\mathrm{CC}$ and/or by following NASH cases with serial liver biopsies ${ }^{(4,7,9,16,17,22,23,26,27,30,31)}$.

Most NASH cases are associated with insulin resistance (IR), so that nonalcoholic fatty liver disease (NAFLD) has been considered the hepatic component of metabolic syndrome (MS) ${ }^{(11,20)}$. Therefore, the MS components, notably central obesity and impaired fasting glycemia, are some of the risk factors for $\mathrm{NASH}$
Despite the difficulty in assigning the $\mathrm{CC}$ etiology to a previous case of NASH, due to the frequent disappearance of the histological markers, the effort is justified by the social impact of the disease. Given the importance of prevention or treatment of liver diseases that could develop to cirrhosis, it is interesting to look for a link between NASH and CC in our midst.

As we have no knowledge about national publications regarding this issue, this study aims to determine the prevalence of risk factors for NASH in CC patients in order to verify if there is a causal relationship between them.

\section{METHODS}

This is a cross-sectional descriptive study, conducted in the Irmandade Santa Casa de Misericórdia de Porto Alegre (ISCMPA), RS, Brazil, between February 2008 and December 2009, through chart review.

\footnotetext{
Declared conflict of interest of all authors: none.

${ }^{1}$ Pós-Graduação em Hepatologia, Universidade Federal de Ciências da Saúde de Porto Alegre (UFCSPA); ${ }^{2}$ rrmandade Santa Casa de Misericórdia de Porto Alegre: ${ }^{3}$ Serviço de Gastroenterologia da UFCSPA, Porto Alegre, RS. Brasil.

Correspondence: Dr. Andrea Benevides Leite - Av. Rui Barbosa, 2.992 - Joaquim Távora - 60115-222 - Fortaleza, CE, Brazil. E-mail: andrea-benevides@hotmail.com
} 
This study included all patients older than 18 years who were followed at the Cirrhosis and Portal Hypertension Outpatient Clinic of ISCMPA and had a diagnosis of:

a) NASH: the patient selection in this group started with a research in the Pathology Department of ISCMPA, analyzing the reports that had a diagnosis of NASH. Then, a chart review was performed to ensure the clinical correlation with histopathology. No patient was biopsied for the purpose of this study. The histological diagnosis of NASH followed Brunt's classification $^{(5)}$.

b) Liver cirrhosis: defined by association of clinical, laboratory, radiologic and endoscopic (gastroesophageal varices) features. There was histopathological analysis in 17 cases of hepatitis $C$ cirrhosis, 8 cases of hepatitis $C$ associated with alcoholic cirrhosis, 2 cases of alcoholic cirrhosis and 17 cases of CC. Cirrhosis was classified according to etiology:

- Hepatitis C (HCV): if the anti-HCV was positive by ELISA 3rd generation test.

- Alcoholic: if there was a history of alcohol consumption greater than $40 \mathrm{~g} /$ day for males (for over 10 years) and $20 \mathrm{~g} /$ day for females (for over 8 years).

- Cryptogenic: when investigation on the causes of liver disease was negative. The records included: no history of alcohol consumption, hepatotoxic drugs capable of inducing chronic liver disease or occupational exposure to hepatotoxins and tests that refuted the presence of any known chronic liver diseases (hepatitis B virus, autoimmune hepatitis, primary or secondary biliary cirrhosis, primary sclerosing cholangitis, hemochromatosis, Wilson's disease and alpha-1 anti-trypsin deficiency).

The exclusion criteria used were: patients less than 18 years old; patients with causes of cirrhosis other than alcohol, HCV or CC; patients with secondary causes of NASH and those with alcoholic steatohepatitis; and those with incomplete medical records that impaired statistical analysis.

The data recording included questions about gender, age, alcohol consumption, weight and height. There were also registered parameters for Child-Pugh classification ${ }^{(25)}$, fasting glucose, total cholesterol (TC), HDL and triglyceride (TG). Tests to exclude other causes of cirrhosis were: HBsAg, anti-nuclear antibody, anti-smooth muscle antibody, anti-mitochondria antibody, ceruloplasmin, 24-hour urine copper, ferritin, transferrin saturation, serum alpha-1 anti-trypsin, and magnetic resonance cholangiography when necessary.

Impaired fasting glucose was defined as glycemia $\geq 100$ $\mathrm{mg} / \mathrm{dL}^{(28)}$. Obesity was defined as BMI (body mass index, calculated by the formula: weight in kilograms / height in meters squared) $\geq 30 \mathrm{~kg} / \mathrm{m}^{2}$, and overweight was defined as BMI between 25 and $29.9 \mathrm{~kg} / \mathrm{m}^{2(29)}$. Hypercholesterolemia was defined as TC $\geq 200 \mathrm{mg} / \mathrm{dL}^{(10)}$. HDL level values were considered low when lower than $40 \mathrm{mg} / \mathrm{dL}$ for males and 50 $\mathrm{mg} / \mathrm{dL}$ for females, while hypertriglyceridemia was considered in the presence of TG levels $\geq 150 \mathrm{mg} / \mathrm{dL}$ according to the criteria of $\mathrm{MS}^{(2)}$.

Patients were divided into three groups, according to the underlying liver disease: Group 1 - patients with NASH; Group 2 - CC; Group 3 - alcoholic/HCV cirrhosis.

This study was approved by the Ethics Committee of the ISCMPA.

Statistical analysis was performed using the prevalence of risk factors for NASH, comparing groups $1 \times 2$ and $2 \times 3$. The $P$ value was considered significant when less than 0.025 , given the design of two primary comparisons (Bonferroni's correction). The data were processed and analyzed using PASW (Predictive Analytic Software for Windows) version 17.

\section{RESULTS}

A total of 290 patients were included. Of those patients, 47 presented with CC, 47 presented with NASH, and 196 presented with cirrhosis secondary to HCV and/or alcohol consumption.

Both cirrhotic groups were homogeneously distributed with respect to the parameters of Child-Pugh classification. The percentage of patients with Child-Pugh B and C was $40.4 \%$ in group 2 and $56.6 \%$ in group $3(P=0.235)$.

The comparison between the profile of groups 1 and 2 can be seen in Table 1 and that between groups 2 and 3, in Table 2 .

TABLE 1. Comparison of laboratorial and demographic profile of patients with cryptogenic cirrhosis and NASH

\begin{tabular}{|c|c|c|c|}
\hline $\begin{array}{l}\text { Clinical } \\
\text { parameters }\end{array}$ & $\begin{array}{l}\text { Cryptogenic } \\
\text { cirrhosis }\end{array}$ & NASH & $P$ \\
\hline Female (\%) & $48.9 \%$ & $68.1 \%$ & 0.06 \\
\hline Age $($ mean $\pm \mathrm{SD})$ & $52 \pm 15.8$ & $46.4 \pm 11.4$ & 0.041 \\
\hline $\begin{array}{l}\text { Fasting glycemia } \\
\geq 100 \mathrm{mg} / \mathrm{dL}(\%)\end{array}$ & $68.2 \%$ & $62.8 \%$ & 0.597 \\
\hline $\mathrm{BMI} \geq 30 \mathrm{~kg} / \mathrm{m}^{2}(\%)$ & $27.5 \%$ & $73.8 \%$ & $<0.001$ \\
\hline $\mathrm{TC} \geq 200 \mathrm{mg} / \mathrm{dL}(\%)$ & $27.9 \%$ & $62.5 \%$ & 0.002 \\
\hline $\mathrm{HDL}_{\text {male }}<40 \mathrm{mg} / \mathrm{dL}(\%)$ & $36.4 \%$ & $53.8 \%$ & 0.574 \\
\hline $\mathrm{HDL}_{\text {female }}<50 \mathrm{mg} / \mathrm{dL}(\%)$ & $81 \%$ & $32 \%$ & $<0.001$ \\
\hline $\mathrm{TG} \geq 150 \mathrm{mg} / \mathrm{dL}(\%)$ & $16.3 \%$ & $61.5 \%$ & $<0.001$ \\
\hline
\end{tabular}

TABLE 2. Comparison of laboratorial and demographic profile of patients with cryptogenic cirrhosis and cirrhosis due to HCV/alcohol

\begin{tabular}{lccc}
\hline \multicolumn{1}{c}{$\begin{array}{c}\text { Clinical } \\
\text { parameters }\end{array}$} & $\begin{array}{c}\text { Cryptogenic } \\
\text { cirrhosis }\end{array}$ & $\begin{array}{c}\text { HCV/alcoholic } \\
\text { cirrhosis }\end{array}$ & $\boldsymbol{P}$ \\
\hline Female $(\%)$ & $48.9 \%$ & $35.2 \%$ & 0.081 \\
Age (mean $\pm \mathrm{SD})$ & $52 \pm 15.8$ & $53.8 \pm 9.6$ & 0.570 \\
$\begin{array}{l}\text { Fasting glycemia } \geq 100 \\
\mathrm{mg} / \mathrm{dL}(\%)\end{array}$ & $68.2 \%$ & $45.2 \%$ & 0.006 \\
$\mathrm{BMI} \geq 30 \mathrm{~kg} / \mathrm{m}^{2}(\%)$ & $27.5 \%$ & $21.1 \%$ & 0.239 \\
$\mathrm{TC} \geq 200 \mathrm{mg} / \mathrm{dL}(\%)$ & $27.9 \%$ & $13.3 \%$ & 0.019 \\
$\mathrm{HDL}$ & $36.4 \%$ & $40.2 \%$ & 0.574 \\
$\mathrm{HDL}$ & $<40 \mathrm{mg} / \mathrm{dL}(\%)$ & $50.8 \%$ & 0.015 \\
$\mathrm{TG} \geq 150 \mathrm{mg} / \mathrm{dL}(\%)$ & $16.3 \%$ & $9.1 \%$ & 0.168 \\
\hline
\end{tabular}


The CC group showed a balanced gender distribution, including 23 females and 24 males. In the NASH group, female patients predominated, although there was no statistically significant difference between $\mathrm{CC}$ and NASH groups. The mean age of patients with $C C$ was 52 years, while that of patients with NASH was 46.4 years $(P<0.05)$. The two groups of cirrhotic patients were similar in age. The prevalence of impaired fasting glucose in patients with $\mathrm{CC}$ was $68.2 \%$, close to what was seen in the NASH group $-62.8 \%$. Comparing the prevalence of impaired fasting glucose in CC group with that of group $3(45.2 \%)$, we found a statistically significant difference. The prevalence of obesity in patients with $\mathrm{CC}$ was $27.5 \%$. In the group with NASH, this value was $73.8 \%$, with a statistically significant difference from that of the CC group. In group 3, the prevalence of obesity was similar to that of the CC group. Regarding the lipid profile analysis, we found that most patients with $\mathrm{CC}$ had normal levels of total cholesterol (72.1\%) and triglycerides (83.7\%). The same pattern was observed in group 3. Low HDL was found in $36.4 \%$ of men with CC, which did not differ statistically from what was seen in the NASH group (53.8\%) or in group $3(40.2 \%)$. Among women, low HDL was found in $81 \%$ of those in the CC group - higher than that found in other groups $(50.8 \%$ in group 3 and $32 \%$ in patients with $\mathrm{NASH}$ ). With regard to hypertriglyceridemia, the prevalence in the CC group was $16.3 \%$, statistically different from that of the NASH group $(61.5 \%)$ and similar to that of the other group of cirrhotic patients $(9.1 \%)$.

\section{DISCUSSION}

Considering that part of the patients with chronic liver disease does not have a final etiological diagnosis determined, we should not spare efforts to identify a causal factor, since only then it would be possible to clearly understand the natural history of the disease. This understanding would lead to a more accurate prognostic vision and therapeutic approach. This study sought to evaluate the existence of a causal relationship between NASH and CC.

With regard to the most prevalent gender in $\mathrm{CC}$, there is disagreement in literature. Some authors ${ }^{(7,22,26,31)}$ have observed a higher prevalence of females, while others ${ }^{(9,30)}$ have observed a higher prevalence of males. In the present study, patients with CC were divided almost equally between genders. This finding is consistent with those cited by Poonawala et al. ${ }^{(23)}$, who, when studying 49 patients with CC, observed $55 \%$ of female and $45 \%$ of male patients; by Ayata et al. ${ }^{(4)}$, who found $52 \%$ of female and $48 \%$ of male patients; and by Sanjeevi et al. ${ }^{(27)}$, with $53 \%$ of male and $47 \%$ of female patients.

Regarding age, patients with $\mathrm{CC}$ evaluated here had a mean age of 52 years, similar to that observed by other authors $^{(22,23)}$. In the literature, articles in which serial liver biopsies in NAFLD were reviewed ${ }^{(1,19,24)}$ demonstrated that NASH can progress to cirrhosis over time. Therefore, patients with cirrhosis secondary to NASH are likely to be older than patients without cirrhosis. This progression can occur in less than 10 years ${ }^{(1,3,12,15,24)}$. In our series, the mean age difference between patients with NASH and those with CC was 6 years, which could suggest a period of time for disease progression.

Concerning the presence of impaired fasting glucose, one of the factors most associated with IR, the present study demonstrated that patients with $\mathrm{CC}$ had a similar percentage to the ones found in the group with NASH (68\% vs $62 \%$ ). Note that this percentage of patients with high glycemia was higher than that described in the literature ${ }^{(7,23,26,31)}$, where this value is around $40 \%-53 \%$. Nevertheless, it is important to remind that these studies considered only the prevalence of diabetes and did not evaluate patients with impaired fasting glucose. Also, the group of patients with cirrhosis due to $\mathrm{HCV} / \mathrm{alcohol}$ had a lower prevalence of impaired fasting glucose.

In this series, the prevalence of obesity in $\mathrm{CC}$ group was $27.5 \%$, higher than that reported by Tellez-Avila et al. ${ }^{(31)}$ $(16.4 \%)$, but lower than that reported by other authors ${ }^{(7,23)}$ (approximately 47\%). In group 3, this prevalence was around $20 \%$, with no statistically significant difference compared with the $\mathrm{CC}$ group. It is unclear whether or not malnutrition secondary to cirrhosis ${ }^{(2)}$ influenced this study by decreasing the number of obese patients. The prevalence of obesity in the NASH group was $73.8 \%$, higher than that found by Caldwell et al. ${ }^{(7)}-64 \%$. This difference may be explained in part by the methodology used. As the NASH group needed the diagnosis confirmed by histopathological examination and no patient was biopsied for the purpose of this study, patients in the NASH group suffered a selection bias (biopsies obtained in patients with more significant and persistent abnormalities in liver panel or in intra-operative bariatric surgery). In any case, patients with NASH were more often obese than those with CC. This contradicts the results by Caldwell et al. ${ }^{(7)}$, which also evaluated patients with NASH without cirrhosis regarding risk factors in the pathogenesis of CC. However, the abovementioned study evaluated the previous history of obesity, while the present study evaluated the current BMI, when the disease had already been established.

It is possible that the proportion of cirrhotic patients with more advanced disease (40.4\% in group 2 and $56.6 \%$ in group 3) has contributed to the finding of normal values of TC and low HDL. It is known that the liver plays a key role in lipid homeostasis and that lipid production decreases with impairment of liver function ${ }^{(14)}$. In the studies by Caldwell et al..$^{(7)}$ and Poonawala et al. ${ }^{(23)}$ there were no assessments of the lipid profile. The only article that evaluates the lipid profile was that by Tellez-Avila et al. ${ }^{(31)}$. However, the article does not distinguish between HDL and TG. Rather, it examines both profiles together. In this article, the authors found a prevalence of dyslipidemia in CC of $54 \%$ versus $6 \%$ in the control group, composed by cirrhotic patients with $\mathrm{HCV}$, alcohol abuse and autoimmune hepatitis. In our series, $72 \%$ of those with CC and $86 \%$ of cirrhotic patients with $\mathrm{HCV}$ and/or alcohol abuse had normal levels of TC, an even higher percentage had normal TG levels, making their lipid profile different from those of the NASH group. As for HDL, there was a difference in pattern between male and female patients. 
With regard to females with $\mathrm{CC}, 81 \%$ had low HDL, as opposed to just half of those in group 3 , with a statistically significant difference. However, this pattern was not repeated in males, as approximately $40 \%$ of both cirrhotic groups had low HDL. While in the NASH group 32\% of the women presented with low HDL, women with $\mathrm{CC}$ had a much higher proportion of low HDL. The analysis of males demonstrated a similar profile between groups.

In general, with the data presented in the current study, from the epidemiological point of view, we cannot conclude that the majority of patients with $\mathrm{CC}$ followed in this study is originated from an evolution of patients with NASH, since the parameters of MS were not similar between these two groups of patients and did not differ significantly from the control group. The only parameters that could support this theory were the mean age of NASH patients, who were younger than patients with $\mathrm{CC}$, and the blood glucose profile of patients with CC, which was similar to that of the NASH group and different from the one of the control group.

Considering the medical literature, it is clear that IR plays a key role in the pathogenesis of NASH. Impaired fasting glucose correlates strongly to IR, as outlined in the consensus of MS of $2005^{(13)}$. According to that study, IR patients were not necessarily clinically obese, but usually had the characteristic of central fat distribution. Therefore, another limitation of this study is that the waist circumference of patients was not evaluated. Instead, it follows the example set by other authors ${ }^{(1,4,5,9)}$ and evaluates BMI. Other parameter that did not demonstrate an association between NASH and CC was the lipid profile. However, one must take into consideration the fact that there are changes in lipid metabolism in cirrhosis due to loss of liver function ${ }^{(14)}$, and that there is a scarcity of studies analyzing these data, thus preventing a better comparison of results.

\section{CONCLUSION}

Evaluating a possible etiologic relationship between NASH and CC, we could not establish a causal link with our results. Only the blood glucose profile, which is a factor strongly associated to IR, and the difference in the mean age, which could suggest a necessary time for the eventual progression from NASH to cirrhosis, are consistent with this hypothesis. Contrary to the findings in much of the current literature, patients in this series did not show strong epidemiological evidence of NASH as a precursor of cryptogenic cirrhosis.

Leite AB, Mattos AA, Mattos AZ, Coral GP, Evaldt S. Fatores de risco para esteatohepatite não-alcoólica na cirrose criptogênica. Arq Gastroenterol. 2012;49(4):-245-9.

RESUMO - Contexto - Em aproximadamente 10\% dos pacientes com doença hepática crônica não é possível identificar um fator etiológico, sendo então rotulados como tendo cirrose criptogênica. Atualmente a esteatohepatite não-alcoólica (EHNA) tem sido considerada como provável etiologia em parcela significativa desses pacientes. Objetivo - Estimar a prevalência de fatores de risco para EHNA em pacientes com cirrose criptogênica com o intuito de verificar uma possível relação causal entre as duas doenças. Métodos - Estudo transversal em que foi avaliado o registro de dados demográficos e laboratoriais de pacientes com cirrose criptogênica com a finalidade de compará-los com aqueles obtidos de um grupo de pacientes com EHNA e de um grupo controle composto de cirróticos por hepatite C (HCV) e/ou álcool. Resultados - Foram avaliados 47 pacientes com cirrose criptogênica, 47 com EHNA e 196 com cirrose por HCV e/ou álcool. A média de idade dos pacientes com cirrose criptogênica foi 52 anos, enquanto a daqueles com EHNA foi 46,4 anos $(P=0,041)$. No grupo com cirosse criptogênica havia 23 mulheres e 24 homens. Naqueles com EHNA predominou o gênero feminino $(68,1 \%)$ e nos cirróticos por HCV e/ou álcool predominou o gênero masculino $(64,8 \%)$, sem diferença estatística entre os grupos. Naqueles com cirrose criptogênica, a prevalência de glicemia de jejum alterada foi $68,2 \%$; obesidade, $27,5 \%$; hipercolesterolemia total, 27,9\%; baixos níveis de HDL, 58,1\% (81\% nas mulheres e 36,4\% nos homens); e hipertrigliceridemia, 16,3\%. A comparação com dados observados nos pacientes com EHNA mostra semelhança estatística entre o perfil glicêmico (62,8\%) e níveis de HDL nos homens (53,8\%). A comparação com os cirróticos relacionados ao HCV e/ou álcool mostra diferença estatística no perfil glicêmico (45,2\%), colesterol total (13,3\%) e HDL nas mulheres (50,8\%). Conclusão - Não foi possível estabelecer uma relação causal entre a EHNA e a cirrose criptogênica. Apenas o perfil glicêmico e os níveis de HDL colesterol nos pacientes masculinos apresentaram semelhanças estatísticas entre os dois grupos de doentes.

DESCRITORES - Cirrose hepática. Fígado gorduroso. Doenças metabólicas. 


\section{REFERENCES}

1. Adams LA, Sanderson S, Lindor KD, Angulo P. The histological course of nonalcoholic fatty liver disease: a longitudinal study of 103 patients with sequential liver biopsies. J Hepatol. 2005;42:132-8.

2. Alberti KG, Eckel RH, Grundy SM, Zimmet PZ, Cleeman JI, Donato KA, Fruchart JC, James WP, Loria CM, Smith SC Jr; International Diabetes Federation Task Force on Epidemiology and Prevention; National Heart, Lung, and Blood Institute; American Heart Association; World Heart Federation; International Atherosclerosis Society; International Association for the Study of Obesity. Harmonizing the metabolic syndrome: a joint interim statement of the International Diabetes Federation Task Force on Epidemiology and Prevention; National Heart, Lung, and Blood Institute; American Heart Association; World Heart Federation; International Atherosclerosis Society; and International Association for the Study of Obesity. Circulation. 2009;120:1640-5.

3. Argo CK, Northup PG, Al-Osaimi AM, Caldwell SH. Systematic review of risk factors for fibrosis progression in non-alcoholic steatohepatitis. J Hepatol. 2009;51:371-9.

4. Ayata G, Gordon FD, Lewis WD, Pomfret E, Pomposelli JJ, Jenkins RL, Khettry U. Cryptogenic cirrhosis: clinicopathologic findings at and after liver transplantation. Hum Pathol. 2002;33:1098-104.

5. Brunt EM, Janney CG, Di Bisceglie AM, Neuschwander-Tetri BA, Bacon BR. Nonalcoholic steatohepatitis: a proposal for grading and staging the histological lesions. Am J Gastroenterol. 1999;94:2467-74.

6. Byron D, Minuk GY. Clinical hepatology: profile of an urban, hospital-based practice. Hepatology. 1996;24:813-5.

7. Caldwell SH, Oelsner DH, Iezzoni JC, Hespenheide EE, Battle EH, Driscoll CJ Cryptogenic cirrhosis: clinical characterization and risk factors for underlying disease. Hepatology. 1999;29:664-9.

8. Clark ME, Ghotb A, Merriman RB. Longitudinal histologic evidence of loss of steatosis with progression of NAFLD to cirrhosis and liver transplantation [abstract]. Gastroenterology. 2009;136(Suppl 1):A847.

9. Duclos-Vallée JC, Yilmaz F, Johanet C, Roque-Afonso AM, Gigou M, Triche C, Féray C, Ballot E, Dussaix E, Castaing D, Bismuth H, Samuel D, Guettier C. Could post-liver transplantation course be helpful for the diagnosis of so called cryptogenic cirrhosis? Clin Transplant. 2005;19:591-9.

10. Expert Panel on Detection, Evaluation, and Treatment of High Blood Cholesterol in Adults. Executive summary of The Third Report of The National Cholesterol Education Program (NCEP) Expert Panel on Detection, Evaluation, and Treatment of High Blood Cholesterol in Adults (Adult Treatment Panel III). JAMA. 2001;285:2486-97.

11. Farrell GC, Larter CZ. Nonalcoholic fatty liver disease: from steatosis to cirrhosis. Hepatology. 2006;43:s99-s112.

12. Fassio E, Álvarez E, Domínguez N, Landeira G, Longo C. Natural history of nonalcoholic steatohepatitis: a longitudinal study of repeat liver biopsies. Hepatology. 2004;40:820-6.

13. Grundy SM, Cleeman JI, Daniels SR, Donato KA, Eckel RH, Franklin BA, Gordon DJ, Krauss RM, Savage PJ, Smith SC Jr, Spertus JA, Costa F, American Heart Association; National Heart, Lung, and Blood Institute. Diagnosis and management of the metabolic syndrome: an American Heart Association/ National Heart, Lung, and Blood Institute Scientific Statement. Circulation. 2005; 112:2735-52.

14. Habib A, Mihas AA, Abou-Assi SG, Williams LM, Gavis E, Pandak WM, Heuman DM. High-density lipoprotein cholesterol as an indicator of liver function and prognosis in noncholestatic cirrhotics. Clin Gastroenterol Hepatol. 2005;3:286-91.
15. Harrison SA, Torgerson S, Hayashi PH. The natural history of nonalcoholic fatty liver disease: a clinical histopathological study. Am J Gastroenterol. 2003;98:2042-7.

16. Heringlake S, Schütte A, Flemming P, Schmiegel W, Manns MP, Tillmann HL. Presumed cryptogenic liver disease in Germany: high prevalence of autoantibody-negative autoimmune hepatitis, low prevalence of NASH, no evidence for occult viral etiology. Z Gastroenterol. 2009;47:417-23.

17. Kim WR, Poterucha JJ, Porayko MK, Dickson ER, Steers JL, Wiesner RH Recurrence of nonalcoholic steatohepatitis following liver transplantation Transplantation. 1996;62:1802-5.

18. Kodali VP, Gordon SC, Silverman AL, McCray DG. Cryptogenic liver disease in the United States: further evidence for non-A, non-B, non-C hepatitis. Am J Gastroenterol. 1994;89:1836-9.

19. Lee, RG. Nonalcoholic steatohepatitis: a study of 49 patients. Human Pathol. 1989;20:594-8.

20. Marchesini G, Brizi M, Bianchi G, Tomassetti S, Bugianesi E, Lenzi M, McCullough AJ, Natale S, Forlani G, Melchionda N. Nonalcoholic fatty liver disease - a feature of the metabolic syndrome. Diabetes. 2001;50:1844-50.

21. Mezey E. Liver disease and nutrition. Gastroenterology. 1978;74:770-83.

22. Ong J, Younossi ZM, Reddy V, Price LL, Gramlich T, Mayes J, Boparai N Cryptogenic cirrhosis and posttransplantation nonalcoholic fatty liver disease. Liver Transpl. 2001;7:797-801.

23. Poonawala A, Nair SP, Thuluvath PJ. Prevalence of obesity and diabetes in patients with cryptogenic cirrhosis: a case-control study. Hepatology. 2000;32:689-92.

24. Powell EE, Cooksley WG, Hanson R, Searle J, Halliday JW, Powell LW. The natural history of nonalcoholic steatohepatitis: a follow-up study of forty-two patients for up to 21 years. Hepatology. 1990;11:74-80.

25. Pugh RN, Murray-Lyon IM, Dawson JL, Pietroni MC, Williams R. Transection of the oesophagus for bleeding oesophageal varices. Br J Surg. 1973;60:646-9.

26. Sakugawa H, Nakasone H, Nakayoshi T, Kawakami Y, Yamashiro T, Maeshiro T, Kobashigawa K, Kinjo F, Saito A. Clinical characteristics of patients with cryptogenic liver cirrhosis in Okinawa, Japan. Hepatogastroenterology. 2003;50:2005-8.

27. Sanjeevi A, Lyden E, Sunderman B, Weseman R, Ashwathnarayan R, Mukherjee S. Outcomes of liver transplantation for cryptogenic cirrhosis: a single-center study of 71 patients. Transplant Proc. 2003;35:2977-80.

28. Sociedade Brasileira de Endocrinologia e Metabologia. Diabetes mellitus: classificação e diagnóstico [Internet]. Associação Médica Brasileira/Conselho Federal de Medicina; elaboração final 4/6/2004. [acessado em 07/10/2008]. Available from: http://www.projetodiretrizes.org.br/4_volume/6-diabetes-c.pdf.

29. Sociedade Brasileira de Endocrinologia e Metabologia. Obesidade: tratamento [Internet]. Associação Médica Brasileira/Conselho Federal de Medicina; elaboração final 17/4/2006. [acessado em 07/10/2008]. Available from: http://www. projetodiretrizes.org.br/4_volume/23-obesidadetratamento.pdf.

30. Sutedja DS, Gow PJ, Hubscher SG, Elias E. Revealing the cause of cryptogenic cirrhosis by posttransplant liver biopsy. Transplant Proc. 2004;36:2334-7.

31. Tellez-Avila FI, Sanchez-Avila F, García-Saenz-De-Sicilia M, Chavez-Tapia NC Franco-Guzman AM, Lopez-Arce G, Cerda-Contreras E, Uribe M. Prevalence of metabolic syndrome, obesity and diabetes type 2 in cryptogenic cirrhosis. World J Gastroenterol. 2008; 14:4771-5.

32. Vedana EH, Peres MA, Neves J, Rocha GC, Longo GZ. Prevalência de obesidade e fatores potencialmente causais em adultos em região do Sul do Brasil. Arq Bras Endocrinol Metab. 2008;52:1156-62.

Received 20/3/2012 Accepted 11/10/2012 